\title{
KEHIDUPAN SOSIAL MASYARAKAT DI SEKITAR PELABUHAN TRISAKTI
}

\author{
Noraidarayanti \\ Email: 2010128220011@mhs.ulm.ac.id \\ Program Studi Pendidikan IPS Fakultas Keguruan dan Ilmu Pendidikan \\ Universitas Lambung Mangkurat \\ Banjarmasin
}

\begin{abstract}
Abstrak
Dalam kehidupan sehari-hari, manusia melakukan hubungan sosial dengan individu lain ataupun dengan kelompok-kelompok tertentu. Hubungan sosial yang terjadi antar ndividu ataupun antar kelompok dikenal dengan istilah interaksi sosial. Proses sosial yang terjadi dalam masyarakat tidak selalu berjalan dengan lancar, hal ini dikarenakan pendukung masyarakat memiliki berbagai macam karakteristik. Keragaman hubungan sosial dalam suatu masyarakat dapat terjadi karena memiliki perbedaan kebudayaan.
\end{abstract}

\section{PENDAHULUAN}

Kehidupan sosial adalah suatu cerminan dari situasi yang terjadi dalam ruang lingkup masyarakat sekitar. Kemajuan suatu masyarakat tentunya tidak dapat lepas dari pengaruh internal ataupun pengaruh eksternal yang dapat terjadi. Di lingkungan masyarakat terdiri dari beberapa komunitas penduduk yang berkelompok dan bekerjasama secara sadar dilakukan. Mulyadi S. (2003: 36) mengelompokkan jenis penduduk berdasarkan ciri-ciri sebagai berikut:

a. Geografis. Kelompok ini terbentuk berdasarkan tempat tinggal.

b. Ekonomi. Kelompok ini meliputi penduduk yang aktif dalam ekonomi seperti berdasarkan tingkat pendapatan ataupun jenis pekerjaan.

c. Biologis. Kelompok ini terbentuk berdasarkan umur ataupun jenis kelamin. 
d. Sosial. Yang meliputi tingkat pendidikan ataupun status perkawinan.

Dalam kehidupan sosial di masyarakat saat ini terdapat beberapa ancaman yang dapat merusak tatanan nilai dalam masyarakat. Buchori (2001: 79-80) berpendapat bahwa ada beberapa hal yang dapat mengancam ketahanan sosial masyarakat antara lain adalah ketidakadilan, kekuasaan, keberingasan sosial, perilaku sosial yang dapat menyimpang, gaya hidup sosial yang berubah, serta perubahan tata nilai.

\section{METODE PENELITIAN}

Metode yang digunakan dalam penulisan artikel ini adalah menggunakan metode kepustakaan yang dimana melakukan pengumpulan berbagai referensi dari sumber tertulis seperti buku, artikel, jurnal, skripsi, dan tesis. Kemudian dari berbagai referensi tersebut diteliti sehingga dapat terbentuk sebuah tulisan pada artikel ini.

\section{KEHIDUPAN SOSIAL MASYARAKAT DI SEKITAR PELABUHAN TRISAKTI}

Manusia adalah makhluk sosial yang dimana mereka tidak dapat hidup sendiri dalam menjalankan kehidupannya. Walaupun seseorang tersebut merupakan individu yang dapat dikatakan anti sosial, namun mereka tetap memerlukan bantuan orang lain. Keterbatasan kemampuan berfikir ataupun kemampuan fisik dari itulah menjadi sebuah alasan mengapa manusia saling membutuhkan satu sama lain. Selain itu hal tersebut juga merupakan sebuah kodrat dari sang maha pencipta.

Kehidupan sosial masyarakat di sekitar pelabuhan Trisakti sangat erat kaitannya dengan pola ekonomi antar masyarakat. Selain itu perubahan sosial sering terjadi di tengah masyarakat sekitar di mana mereka mulai menggunakan teknologi seperti smartphone dan lebih memilih berbelanja online dibandingkan berbelanja di warung warga sekitar.

Pada umumnya perekonomian masyarakat sekitar pelabuhan Trisakti banyak masyarakat yang memiliki pekerjaan sebagai buruh, pedagang dan usaha penginapan. Hal itu terjadi dikarenakan banyaknya barang yang perlu diangkut dari pelabuhan dan memerlukan bantuan buruh untuk membantu mengangkut barang yang berada dikapal dan dipindahkan ke masingmasing truk sehingga dapat dikirim ke berbagai daerah sekitar. Selain itu masyarakat sekitar juga banyak yang menjadi pedagang, hal itu dikarenakan banyaknya pekerja yang berada di 
pelabuhan sehingga mereka terkadang memerlukan bahan makanan ataupun minum. Selain itu tempat penginapan juga banyak di daerah sekitar pelabuhan trisakti, karena banyaknya turis yang masih menggunakan kapal sebagai alat trasportasi dan mereka memerlukan penginapan.

Selain itu masyarakat di sekitar pelabuhan Trisakti juga banyak yang memiliki pekerjaan sebagai tenaga bongkar muat, yaitu dimana pekerjaan tersebut adalah bekerja sebagai bongkar dan muat batubara dan barang dari kontainer. Selain itu banyak juga perusahaan ekspedisi disekitar pelabuhan Trisakti.

Pelabuhan Trisakti menjadi pusat mata pencaharian warga sekitar. Namun adapun beberapa dampak dari pengaruh warga asing terhadap warga sekitar misalnya seperti, budaya sosial yang berubah, lingkungan sekitar menjadi kumuh dan kotor dikarenakan kurang terawatnya lingkungan sekitar. Selain itu pengaruh dari budaya luar cepat sekali mempengaruhi warga sekitar dikarenakan mereka lah yang berinteraksi langsung dengan para pendatang.

Cara menghindari hal tersebut adalah dengan cara menyaring dan memilah budaya asing yang masuk sehingga dapat diambil yang bersifat positif saja dan meninggal sisi negatif dari hal tersebut. Selain itu kita juga dapat mengurangi interaksi antara para pendatang dan berinteraksi sewajarnya saja sehingga dengan hal tersebut dapat mengurangi terjadinya pengaruh dari perubahan budaya.

\section{SIMPULAN}

Dalam kehidupan sosial di masyarakat saat ini terdapat beberapa ancaman yang dapat merusak tatanan nilai dalam masyarakat. Buchori (2001: 79-80) berpendapat bahwa ada beberapa hal yang dapat mengancam ketahanan sosial masyarakat antara lain adalah ketidakadilan, kekuasaan, keberingasan sosial, perilaku sosial yang dapat menyimpang, gaya hidup sosial yang berubah, serta perubahan tata nilai. Kehidupan sosial masyarakat di sekitar pelabuhan Trisakti sangat erat kaitannya dengan pola ekonomi antar masyarakat. Selain itu perubahan sosial sering terjadi di tengah masyarakat sekitar di mana mereka mulai menggunakan teknologi seperti smartphone dan lebih memilih berbelanja online dibandingkan berbelanja di warung warga sekitar. 


\section{REFERENSI}

Mangatta, B. H. (2016). Strategi Adaptasi Tukang Becak dalam Kehidupan Sosial Ekonomi (Studi Kasus Tukang Becak di Kelurahan Bontobiraeng Kecamatan Mamajang Kota Makassar). HOLISTIK, Journal Of Social and Culture.

Norhayati, N., Abbas, E. W., \& Putra, M. A. H. (2019). Social Interaction Pattern Jelai Riverbanks South Basirih. The Innovation of Social Studies Journal, 1(1), 12-20.

Plekhanov, G. V. (2006). seni dan kehidupan sosial.

Putro, H. P. N., Jumriani, J., Darmawan, D., \& Nuryatin, S. (2020). Social Life of the Community: Perspective of Riverbanks Community in Sungai Jingah, Banjarmasin. The Kalimantan Social Studies Journal, 1(2), 151-158.

Setiadi, E. M. (2017). Ilmu sosial \& budaya dasar. Kencana.

Tumanggor, R., Ridlo, K., \& H Nurochim, M. M. (2017). Ilmu Sosial dan Budaya Dasar. Kencana. 